\title{
Metakognisi Siswa SMA dalam Menyelesaikan Masalah Matematika
}

\author{
Usman Mulbar $^{1, a)}$, Alimuddin ${ }^{1, b)}$, dan St. Mukarramah ${ }^{1, c)}$ \\ ${ }^{1}$ Jurusan Matematika, FMIPA, Universitas Negeri Makassar \\ ${ }^{a)}$ u_mulbar@unm.ac.id \\ b)alimuddin@unm.ac.id \\ ${ }^{c)}$ st.mukarramahhh@gmail.com
}

\begin{abstract}
Abstrak. Penelitian ini merupakan penelitian deskriptif yang bertujuan untuk mendeskripsikan metakognisi siswa SMA dalam menyelesaikan masalah matematika ditinjau dari kemampuan akademik siswa. Subjek penelitian merupakan siswa kelas XI pada salah satu SMA yang dipilih berdasarkan kriteria tertentu dengan teknik snowball sampling. Pengumpulan data dilakukan dengan pemberian tes pemecahan masalah yang didukung oleh data hasil wawancara. Berdasarkan hasil penelitian dapat disimpulkan bahwa, siswa berkemampuan matematika tinggi dan rendah memiliki kesadaran tentang fakta yang dimilikinya dan menyadari bagaimana menggunakan suatu strategi, namun hanya siswa berkemampuan tinggi yang memiliki kesadaran kapan dan mengapa suatu strategi seharusnya diterapkan. Hal ini menunjukkan bahwa dalam menyelesaikan masalah matematika, siswa berkemampuan akademik tinggi melibatkan tiga aspek pengetahuan metakognitif yakni pengetahuan deklaratif, pengetahuan prosedural, dan pengetahuan kondisional dengan baik sedangkan, siswa berkemampuan akademik rendah hanya mampu melibatkan dua aspek pengetahuan metakognitif yakni pengetahuan deklaratif dan pengetahuan prosedural.
\end{abstract}

Kata Kunci: Metakognisi, Pengetahuan Metakognitif, Menyelesaikan Masalah Matematika

\begin{abstract}
This research is a descriptive research that aims to describe the metacognition of high school students in solving mathematical problems regarding students' academic abilities. The subjects were students in grade XI on a High School that selected based on certain criteria with snowball sampling technique. The data were collected through problem-solving test which was supported by interview data. Based on the research result, can be concluded that students with high and low academical abilities had an awareness of the facts they had and were aware of how to use a strategy. However, only high-ability students had an awareness of when and why a strategy should be applied. It showed that in solving mathematical problems students with high academical ability involve three aspects of metacognitive knowledge namely declarative knowledge, procedural knowledge, and conditional knowledge nicely, while students with low academical ability only involve two aspects of metacognitive knowledge i.e declarative knowledge and procedural knowledge.
\end{abstract}

Keywords: Metacognition, Metacognitive Knowledge, Mathematical Problem-solving

\section{PENDAHULUAN}

Matematika memiliki objek dasar abstrak yang menyebabkan kebanyakan siswa merasa matematika sulit, membosankan dan memusingkan. Mulbar, Rahman, dan Ahmar (2017) menyatakan bahwa matematika menjadi momok menakutkan bagi sebagian besar siswa karena siswa merasa sulit untuk menyelesaikan masalah matematika. Pada proses pembelajaran matematika di sekolah, guru biasanya menyajikan masalah matematika untuk dipecahkan oleh siswa dalam bentuk soal berupa pertanyaan yang membutuhkan jawaban atau tugas yang harus diselesaikan. Masalah matematika yang diberikan dimaksudkan untuk melatih siswa 
mematangkan kemampuanya dalam memahami, merencanakan, melakukan, dan memperoleh solusi dari setiap masalah yang dihadapinya.

Melalui pemecahan masalah matematika, siswa diarahkan untuk mengembangkan kemampuannya antara lain membangun pengetahuan matematika yang baru dan memecahankan masalah dalam berbagai konteks yang berkaitan dengan matematika. Hal ini sejalan dengan pendapat Gartman dan Freiberg (1993) bahwa tujuan utama mengajarkan pemecahan masalah dalam matematika bukan hanya untuk melengkapi siswa dengan sekumpulan keterampilan atau prosedur penyelesaian, tetapi lebih kepada memungkinkan siswa berpikir tentang apa yang dipikirkannya. Berpikir tentang apa yang dipikirkan berkaitan dengan kesadaran diri dalam hal ini adalah metakognisi.

Metakognisi merupakan kesadaran berpikir seseorang tentang proses berpikirnya sendiri, dimana kesadaran berpikir adalah kesadaran seseorang tentang apa yang diketahui, apa yang tidak diketahui dan apa yang akan dilakukan (Flavell, 1976; Gama, 2004; Mulbar, 2008). Dengan melibatkan metakognisi dalam menyelesaikan masalah matematika, memungkinkan siswa membangun pemahaman yang kuat dan menyeluruh terhadap masalah yang disertai dengan alasan yang logis (Anggo, 2011).

Beberapa penelitian menunjukan proses metakognisi pada siswa (Laurens, 2011; Shanon, 2008; Tobias \& Everson, 1998; Young \& Fry, 2008; Kartika, Riyadi, \& Sujadi, 2015). Laurens (2011) menyatakan bahwa kenyataan yang terjadi dalam banyak kelas matematika adalah pembelajar kurang memanfaatkan metakognisi mereka ketika menyelesaikan masalah, sehingga mereka tidak memahami apa yang dipelajarinya. Young \& Fry (2008) mendapatkan hasil hubungan yang signifikan antara metakognisi dan kemampuan akademik. Prestasi akademik siswa dengan kemampuan akademik yang berbeda-beda baik kemampuan tinggi, sedang, dan rendah dipengaruhi oleh aktivitas metakognisi yang dilakukan. Kartika,dkk (2015) menyatakan bahwa proses metakognisi siswa dengan kemampuan akademik tinggi, sedang, dan rendah menunjukan hasil berbeda dalam menyusun rencana tindakan, memonitor tindakan, mengembangkan rencana solusi, dan evaluasi tindakan.

Penelitian ini dilakukan dengan tujuan untuk memberikan gambaran mengenai pengetahuan metakognitif siswa untuk tingkatan akademik tinggi dan rendah. Pengetahuan metakognitif yang dimaksud dalam penelitian ini yaitu pengelompokan metakognitif berdasarkan ciri-ciri kesadaran siswa dalam menyelesaikan tes pemecahan masalah.

\section{KAJIAN PUSTAKA}

Metakognisi ialah istilah yang diperkenalkan oleh John Hurley Flavell pada tahun 1976 yang didasarkan pada konsep metamemori. Kemunculan istilah metakognisi sebagai hasil dari perenungan oleh beberapa ahli psikolog terhadap kondisi mengapa ada orang yang belajar dan mampu mengingat lebih banyak dari yang lainnya. Flavell (1976) mendefinisikan metakognisi sebagai pengetahuan seseorang mengenai proses dan hasil kognisinya atau segala sesuatu yang berhubungan dengannya.

Dalam pendefinisiannya, metakognisi tidak selalu sama di dalam berbagai macam bidang penelitian psikologi, dan juga tidak dapat diterapkan pada satu bidang psikologi saja. Wellman (1985) mendefinisikan metakognisi secara sederhana sebagai berpikir tentang berpikir atau kognisi seseorang tentang kognisi. Selain itu, Dirkes (1985) mendefinisikan metakognisi sebagai berpikir tentang berpikir, yaitu mengetahui apa yang diketahui dan apa yang tidak diketahui. Brown (1978) juga mendefinisikan metakognisi sebagai kesadaran dan organisasi proses berpikir siswa yang mereka gunakan dalam merencanakan pembelajaran dan situasi pemecahan masalah. Ayersman (1995) menyatakan bahwa metakognisi terjadi sebagai hasil dari 
evaluasi individu seseorang dan observasi perilaku kognitif mereka dalam lingkungan pembelajaran.

Metakognisi meliputi dua komponen, yaitu pengetahuan metakognitif dan pengalaman atau regulasi metakognisi (Flavell, 1976). Selain itu, Huitt (1997) juga berpendapat bahwa terdapat dua komponen yang termasuk dalam metakognisi, yaitu apa yang kita ketahui atau tidak ketahui, dan regulasi bagaimana kita belajar. Selain itu, Tobias \& Everson (1998) menyatakan metakognisi sebagai gabungan dari pengetahuan metakognitif dan keterampilan metakognitif yang bersifat hirarkis, dimana pengetahuan metakognitif adalah suatu prasyarat untuk mengaktifkan keterampilan metakognitif.

Belakangan ini, perbedaan paling umum dalam metakognisi adalah memisahkan pengetahuan metakognitif dari keterampilan metakognitif (Mulbar, 2008). Secara umum, komponen metakognitif dapat dilihat pada Tabel 1.

TABEL 1. Komponen Metakognitif

\begin{tabular}{|c|c|c|}
\hline Komponen & Indikator & Deskripsi \\
\hline \multirow{4}{*}{$\begin{array}{l}\text { Pengetahuan } \\
\text { Metakognitif }\end{array}$} & Pengetahuan & kesadaran tentang fakta dan konsep-konsep matematika yang \\
\hline & Deklaratif & $\begin{array}{l}\text { dimiliki seseorang atau faktor-faktor yang mempengaruhi } \\
\text { pemikirannya dan perhatiannya }\end{array}$ \\
\hline & $\begin{array}{l}\text { Pengetahuan } \\
\text { Prosedural }\end{array}$ & $\begin{array}{l}\text { kesadaran seseorang tentang bagaimana cara menggunakan suatu } \\
\text { strategi }\end{array}$ \\
\hline & $\begin{array}{l}\text { Pengetahuan } \\
\text { Kondisional }\end{array}$ & $\begin{array}{l}\text { kesadaran seseorang akan kondisi yang mempengaruhi belajarnya, } \\
\text { yaitu: kapan suatu strategi seharusnya diterapkan, mengapa } \\
\text { menerapkan suatu strategi, dan kapan strategi yang diterapkan itu } \\
\text { tepat }\end{array}$ \\
\hline \multirow[t]{4}{*}{$\begin{array}{l}\text { Keterampilan } \\
\text { Metakognitif }\end{array}$} & Prediksi & $\begin{array}{l}\text { kegiatan kognititf seseorang untuk membedakan antara masalah } \\
\text { mana yang mudah atau sulit dan masalah mana yang mungkin } \\
\text { membutuhkan lebih banyak keterampilan atau upaya untuk } \\
\text { menyelesaikannya }\end{array}$ \\
\hline & Perencanaan & $\begin{array}{l}\text { Kegiatan berpikir awal seseorang tentang bagaimana, kapan, dan } \\
\text { mengapa melakukan tindakan guna mencapai tujuan melalui } \\
\text { serangkaian tujuan khusus menuju kepada tujuan utama } \\
\text { permasalahan (tugas) }\end{array}$ \\
\hline & Monitoring & $\begin{array}{l}\text { Pengawasan seseorang terhadap strategi kognitif yang } \\
\text { dipergunakannya selama kegiatan pembelajaran berlangsung, guna } \\
\text { mengenali masalah dan memodifikasi rencana }\end{array}$ \\
\hline & Evaluasi & $\begin{array}{l}\text { Retroperspective yang dilakukan dengan melihat kembali strategi } \\
\text { yang telah ia gunakan dan apakah strategi tersebut } \\
\text { mengarahkannya pada hasil yang diinginkan atau tidak dalam } \\
\text { pembelajaran. }\end{array}$ \\
\hline
\end{tabular}

Berdasarkan penelitian yang dilakukan oleh Kartika, dkk (2015) menunjukkan bahwa proses metakognisi siswa dengan kemampuan akademik tinggi, sedang, dan rendah menunjukan hasil berbeda dalam menyusun rencana tindakan, memonitor tindakan, mengembangkan rencana solusi, dan evaluasi tindakan. Siswa dengan kemampuan akademik tinggi dan sedang mampu menyadari proses berpikirnya saat menyusun rencana tindakan, membuat rencana solusi, memonitor tindakan, dan mengevaluasi tindakannya. Berbeda dengan siswa yang memiliki kemampuan akademik rendah yang sulit menyadari proses berpikirnya dalam 4 aspek tersebut. 


\section{METODE PENELITIAN}

Jenis penelitian yang digunakan adalah jenis penelitian deskriptif dengan pendekatan kualitatif, penelitian dilaksanakan di kelas XI pada salah satu SMA. Subjek dalam penelitian ini terdiri dari siswa berkemampuan aademik tinggi dan rendah. Teknik pengambilan subjek yakni snowball sampling dimana dipilih 1 orang siswa dari masing-masing tingkatan kemampuan akademik tinggi dan rendah sehingga terpilih 2 siswa sebagai informan pertama. Hingga data jenuh, terpilih 4 subjek penelitian yang terdiri dari 2 subjek berkemampuan tinggi dan 2 subjek berkemampuan rendah. Instrumen yang digunakan yaitu tes pemecahan masalah dan pedoman wawancara yang telah divalidasi oleh dua orang ahli.

Pengambilan data dalam penelitian ini dimulai dengan pemberian instrumen tes pemecahan masalah, kemudian dianalisis dan dikategorisasi berdasarkan kriteria pengetahuan metakognitif siswa. Data hasil tes tersebut dideskripsikan berdasarkan tingkat kemampuan akademik siswa. Langkah selanjutnya adalah wawancara informan untuk menggali data-data pengetahuan metakognitif siswa guna memperjelas data hasil tes yang tidak dapat dijelaskan melalui analisis hasil jawaban tes tertulis. Data yang diperoleh saat wawancara kemudian dideskripsikan. Terakhir, data hasil tes dan wawancara tersebut disajikan dalam bentuk uraian.

\section{HASIL DAN PEMBAHASAN}

Pada bagian ini didekskripsikan data hasil penelitian yaitu hasil tes pemecahan masalah dan jenis-jenis pengetahuan metakognitif yang dimiliki siswa berdasarkan tingkat kemampuan akademik tinggi dan rendah.

\section{Deskripsi Pengetahuan Metakognitif Siswa berkemampuan Akademik Tinggi (ST)}

\section{Pengetahuan Deklaratif}

Berikut ini disajikan hasil tes dan petikan wawancara salah satu siswa yang menunjukkan adanya penerapan pengetahuan deklaratif dalam menyelesaikan masalah matematika.

\begin{tabular}{|l|lr|}
2)$. & $\begin{array}{l}\text { Dik. berkurang setenganny a 20thn } \\
2007: 500.000 \text { ekor }\end{array}$ & $U_{n}=a \cdot r^{n-1}$ \\
& olt. $1887 \ldots$ ? & $\frac{U_{n}}{U_{n-1}}$ \\
\hline
\end{tabular}

GAMBAR 1. Paparan hasil tes ST

Gambar 1 menunjukkan bahwa ST mampu mengidentifikasi informasi pada soal yakni dengan menuliskan apa yang diketahui dan apa yang ditanyakan. ST juga menuliskan rumus yang dapat digunakan untuk menyelesaikan masalah, yakni rumus suku ke-n dan rasio deret geometri. Hal ini dipertegas pada transkrip 1.

\section{TRASNKRIP 1}

W-19 : Apa saja yang kamu pikirkan ketika melihat soal ini?

ST12-W19 : Kupikir berkaitan dengan deret geometri kak

W-33 : Menurutmu, apa itu deret geometri?

ST12-W33 : Deret geometri itu kakak deret yang pakai perbandingan atau rasio. Dari soalnya, tahun selanjutnya itu kakak berkurang jadi setengahnya jadi pakai rasio kakak

W-23 : Oke jadi informasi apa saja yang kamu peroleh?

ST12-W23 : Pada tahun 2007 ada 500 rb ekor satwa, setiap 20 tahun berkurang setengah dari tahun sebelumnya kak, terus ditanyakan banyaknya satwa di tahun 1887 kak

W-24 : Untuk apa kamu tulis diketahui dan ditanyakan? 


\section{ST12-W24 : Biar saya tidak capek baca ulang soalnya dan lebih mudah juga menyelesaikan} soal

Pada transkrip 1, terlihat bahwa ST menyadari konsep dan pengetahuan awal yang dibutuhkan untuk menyelesaikan permasalahan yakni dengan mengunakan konsep deret geometri (ST12W19). ST memikirkan konsep tersebut dengan mempertimbangkan informasi yang ada pada soal yakni karena adanya rasio (ST12-W33). Hal ini menunjukkan ST memanfaatkan pengetahuan yang telah diperoleh sebelumnya untuk memahami masalah. Selanjutnya, ST juga menjelaskan alasan menuliskan informasi yang ia peroleh pada soal yakni untuk mempermudahnya dalam menyelesaikan permasalahan (ST12-W24). Hal ini menunjukkan ST menyadari esensi menuliskan apa yang diketahui dan ditanyakan yakni untuk mencapai tujuan yang diinginkan.

Berdasarkan gambar 1 dan transkrip 1 menunjukkan bahwa ST cenderung memiliki kesadaran tentang fakta matematika dan konsep atau pengetahuan awal yang dibutuhkan untuk membantunya menyelesaikan masalah. Oleh karena itu, dapat dikatakan bahwa ST menerapkan pengetahuan metakognitif terkait pengetahuan deklaratif dalam menyelesaikan masalah matematika.

\section{Pengetahun Prosedural}

Berikut ini disajikan hasil tes dan petikan wawancara salah satu siswa yang menunjukkan adanya penerapan pengetahuan deklaratif dalam menyelesaikan masalah matematika.

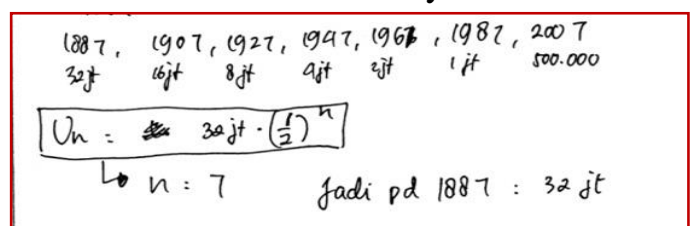

GAMBAR 2. Paparan hasil tes ST

Gambar 2 menunjukkan bahwa dalam menyelesaikan masalah, ST mencari solusi dengan membangun langkah penyelesaiannya sendiri, tanpa menggunakan rumus. ST mendaftar satu persatu jumlah satwa yang ada setiap tahunnya dengan menghitung mundur jumlah satwa mulai tahun 2007 sampai tahun 1887. ST menggunakan rumus untuk mengevaluasi hasil pekerjaannya. Hal ini dipertegas pada transkrip 2.

\section{TRASNKRIP 2}

W-26 : Bagaimana langkah-langkahnya kamu selesaikan?

ST12-W26 : Kan setiap maju 20 tahun itu kak, berkurang setengahnya kak, jadi ini (menunjuk $500 \mathrm{rb}$ ) adalah setengah dari tahun yang lalunya, kalau mau mundur ke sebelumnya dikali 2 saja kali 2 dst.

Pada transkrip 2, ST menjelaskan alternatif penyelesaian yang diterapkan dengan memberikan alasan yang jelas (ST12-W26). Dengan menggunakan logika sederhana ST memperoleh jawaban dengan tepat dan cepat. Hal ini menunjukkan ST menerapkan suatu cara untuk menyelesaikan permasalahan.

Berdasarkan gambar 2 dan transkrip 2, menunjukkan bahwa ST cenderung memiliki kesadaran bagaimana menerapkan suatu strategi secara menyeluruh untuk menyelesaikan masalah. Sehingga dapat dikatakan bahwa ST menerapkan pengetahuan metakognitif terkait pengetahuan prosedural dalam menyelesaikan masalah matematika.

\section{Pengetahuan Kondisional}

Salah satu penerapan pengetahuan kondisional ST dapat dilihat pada transkrip 3. 


\section{TRANSKRIP 3}

W-41 : Kenapa rumus deret geometri yang kamu gunakan?

ST22-W41 : Karena ini yang di pakai bukan selisih, tapi rasio/perbandingan

W-42 : Kenapa harus perbandingan?

ST22-W42 : Karena berkurang 1/5 tiap tahunnya kak

W-44 : Dari mana kamu tahu bahwa ini soal geometri?

ST22-W44 : Karena biasanya kalau soal deret geometri pasti ada rasionya yang berbentuk pecahan

Pada transkrip 3 terlihat bahwa ST memahami konsep yang berkaitan dengan masalah yang diberikan (ST22-W41), sehingga ST dapat memaparkan alasan menggunakan rumus deret geometri dalam menyelesaikan masalah tersebut (ST22-W44).

Berdasarkan transkrip 3, menunjukkan bahwa ST cenderung memiliki kesadaran kesadaran tentang kapan dan mengapa suatu strategi seharusnya diterapkan. Hal ini menunjukkan subjek melibatkan pengetahuan metakognitif terkait pengetahuan kondisional dalam menyelesaikan masalah matematika.

\section{Deskripsi Pengetahuan Metakognitif Siswa berkemampuan Akademik Rendah (SR)}

\section{Pengetahuan Deklaratif}

Berikut ini disajikan hasil tes dan petikan wawancara salah satu siswa yang menunjukkan adanya penerapan pengetahuan deklaratif dalam menyelesaikan masalah matematika.

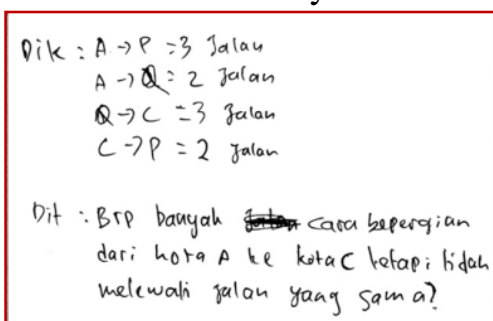

GAMBAR 3. Paparan hasil tes SR

Gambar 3 menunjukkan bahwa SR mampu mengidentifikasi informasi pada soal yakni dengan menuliskan apa yang diketahui dan apa yang ditanyakan dalam permasalahan. Hal ini dipertegas pada transkrip 4.

\section{TRANSKRIP 4}
W-03 $P$ Menurutmu ada tidak rumus atau konsep matematika yang bisa digunakan?
SR11-W03 J Ada kayaknya kak, tapi nda kutauki saya kak
W-06 P Bacaterus?
SR11-W06 J Kubacaberulang-ulang ki kak
W-08 $\quad P$ Setelah kamu baca, coba jelaskan informasi apa yang kamu pahami dari soalnya!
SR11-W08 J Disuruh tentukan berapa jalan kak. Kan keterangannya ada 2 alternatif, melalui kota $P$ atau $Q$. Kan A, $P, C$, dan $Q$ adalah kota sedangkan garis adalah jalan kak Disuruh tentukan berapa jalan, Awalnya saya kira hanya 2 jalan kak

Pada transkrip 4 terlihat bahwa SR belum menyadari konsep yang terkait dengan permasalahan yang diberikan (SR11-W03). SR juga menjelaskan cara yang ia lakukan untuk mengidentifikasi informasi pada soal sebagai upaya untuk memahami masalah (SR11-W06). Selanjutnya, subjek menjelaskan secara lisan informasi yang ia peroleh (SR11-W08). 
Berdasarkan gambar 3 dan transkrip 4 menunjukkan bahwa SR cenderung memiliki kesadaran tentang informasi dalam soal, namun belum menyadari konsep yang dibutuhkan untuk menyelesaikan masalah. Hal ini menunjukkan bahwa subjek menerapkan pengetahuan metakognitif terkait pengetahuan deklaratif dalam menyelesaikan masalah matematika namun belum sempurna.

\section{Pengetahun Prosedural}

Berikut ini disajikan hasil tes dan petikan wawancara salah satu siswa yang menunjukkan adanya penerapan pengetahuan deklaratif dalam menyelesaikan masalah matematika.

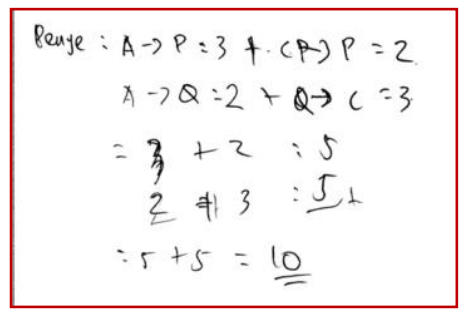

GAMBAR 4. Paparan hasil tes SR

Gambar 4 menunjukkan bahwa dalam menyelesaikan masalah, SR menyelesaikan soal tanpa menerapkan konsep tertentu. Subjek langsung menjumlahkan semua jalan yang ada. Hal ini dipertegas pada transkrip 5.

\section{TRASNKRIP 5}

W-17 $\quad P$ Oke coba jelaskan bagaiamana langkah penyelesaian yang kamu tuliskan dek!

SR11-W17 J Kan dari kota A ke kota P itu kak ada 3 jalan, ditambah $C$ ke kota $P$ itu 2 jalan, terus A kota $Q$ itu 2 jalan, $Q$ ke kota $C$ itu 3 jalan. Jadi saya jumlahkan $3+2=5$, $2+3=5$ dapat $10 \mathrm{kak}$

Pada transkrip 5, SR menjelaskan alternatif penyelesaian yang diterapkan. SR menyelesaikan permasalahan menggunakan analisis sederhana dengan cara coba-coba (SR11-W17). Hal ini menunjukkan SR menerapkan suatu cara untuk menyelesaikan permasalahan namun masih menggunakan strategi mencoba-coba dengan analisis sederhana.

Berdasarkan gambar 4 dan transkrip 5, menunjukkan bahwa SR cenderung belum memiliki kesadaran penuh bagaimana menerapkan suatu strategi dalam rangka mencapai tujuan. Hal ini menunjukkan bahwa subjek SR menerapkan pengetahuan metakognitif terkait pengetahuan prosedural dalam menyelesaikan masalah matematika.

\section{Pengetahuan Kondisional}

Salah satu penerapan pengetahuan kondisional SR dapat dilihat pada transkrip 6.

\section{TRANSKRIP 6}

W-13 P Kenapa di jumlahkan dek?

SR11-W13 J Karena waktu kutulis itu langsung kepikiran kak

W-18 P Disini kenapa pakai operasi penjumlahan dek? Kenapa bukan perkalian atau perpangkatan atau yang lain?

SR11-W18 J Karena kalau saya kali banyak sekali kak

Pada transkrip 6, terlihat bahwa SR melakukan suatu tindakan berdasarkan intuisi (SR11-W13) dan tidak mengetahui dengan pasti alasan penerapan strategi yang digunakannya dalam menyelesaikan masalah (SR11-W18). 
Berdasarkan transkrip 6, menunjukkan bahwa SR belum memiliki kesadaran tentang kapan dan mengapa menerapkan suatu strategi. Hal ini menunjukkan bahwa SR tidak melibatkan pengetahuan metakognitif terkait pengetahuan kondisional dalam menyelesaikan masalah matematika.

\section{KESIMPULAN}

Siswa berkemampuan matematika tinggi dan rendah memiliki kesadaran tentang fakta yang dimilikinya dan menyadari bagaimana menggunakan suatu strategi, namun hanya siswa berkemampuan tinggi yang memiliki kesadaran kapan dan mengapa suatu strategi seharusnya diterapkan. Hal ini menunjukkan bahwa dalam menyelesaikan masalah matematika, siswa berkemampuan akademik tinggi melibatkan tiga aspek pengetahuan metakognitif yakni pengetahuan deklaratif, pengetahuan prosedural, dan pengetahuan kondisional dengan baik. Sedangkan, siswa berkemampuan akademik rendah hanya mampu melibatkan dua aspek pengetahuan metakognitif yakni pengetahuan deklaratif dan pengetahuan prosedural.

\section{DAFTAR PUSTAKA}

Anggo, M. (2011). Pelibatan metakognisi dalam pemecahan masalah matematika. Edumatica: Jurnal Pendidikan Matematika.

Ayersman, D. J. (1995). Effects of Knowledge Representation Format and Hypermedia Instruction on Metacognitive Accuracy. Computers in Human Behavior, 11(3-4). 533555 .

Brown, A. L. (1978). Knowing when, where, and how to remember: A problem of metacognition. In R. Glaser (Ed.), Advances in instructional psychology, 1. 77-165.

Dirkes, M. A. (1985). Metacognition: Students in charge of their thinking. Roeper Review: A Journal on Gifted Education, 8(2). 96-100.

Flavell, J. H. (1976). Metacognitive aspects of problem solving. In L. Resnick, (Ed.). The nature of intelligence. 231-235.

Gama, C. A. (2004). Integrating Metacognition Instruction in Interactive Learning Environment (Disertasi, tidak dipublikasikan). University of Sussex, Falmer.

Gartman, S., \& Freiberg, M. (1993). Metacognition and Mathematics Problem Solving: Helping Students to Ask The Right Questions. The Mathematics Educator, 6(1). 9-13.

Huitt, W. (1997). Metacognition. Educational Psychology Interactive. Valdosta, GA: Valdosta State University.

Kartika, D.L., Riyadi, \& Sujadi, I. (2015). Proses Metakognisi dalam Pemecahan Masalah Matematika pada Siswa Kelas XI di SMA Negeri Banyumas. Jurnal Elektronik Pembelajaran Matematika, 3(9), 1021-1034.

Laurens, T. (2011). Pengembangan Metakognisi Dalam Pembelajaran Matematika. Disajikan dalam seminar nasional matematika Juli 2011.

Mulbar, U. (2008). Metakognisi Siswa Dalam Menyelesaikan Masalah Matematika. Disajikan pada seminar nasional pendidikan matematika 2008. 
Mulbar, U., Rahman, A., \& Ahmar, A. (2017). Analysis of Ability in Mathematical ProblemSolving Based on Solo Taxonomy and Cognitive Style. World Transactions on Engineering and Technology Education, 15(1).

Shanon, S.V. (2008). Using Metacognition Strategies and Learning Styles to Create SelfDirected Learners. Institute for Learning Styles Journal, 1, 1-15.

Tobias, S., \& Everson, H. T. (1998). Assessing Metacognitive Knowledge Monitoring. College Board Report No.96-01. New York: The College Board.

Wellman, H., (1985). The Origins of Metacognition. In D.L.Forrest-Pressley, G.E.MacKinnon, and

T.G. Waller (eds.), Metacognition, Cognition, and Human Performance, 1(1).

Young, A., \& Fry, J. D. (2008). Metacognitive Awareness and Academic Achievement in College Students. Journal of the Scholarship of Teaching and Learning, 8. 1-10. 